\title{
FEMALE PEREGRINE FALCON (FALCO PEREGRINUS) EXPLOITS FISH AS PREY
}

\author{
Brent Carl Hetzler ${ }^{1}$
}

\begin{abstract}
Most descriptions of food utilized by Peregrine Falcons (Falco peregrinus) list birds as the primary food source. Here, I report on an adult female Peregrine Falcon that learned how to acquire fish and then continually exploited this unusual source of food to feed her young.

Resumen.-La mayoría de las descripciones del alimento utilizado por el Halcón Peregrino (Falco peregrinus) incluyen a las aves como la fuente principal de alimento. Aquí, reporto sobre una hembra adulta de Halcón Peregrino que aprendió a capturar peces y luego a explotar continuamente esta fuente inusual de alimento para alimentar a sus crías.
\end{abstract}

Most descriptions of food utilized by Peregrine Falcons (Falco peregrinus) list birds as the primary food source (White et al. 2002). Sherrod (1978) summarized diets from 14 published studies of Falconiformes and found that all researchers listed "birds" and most researchers listed "some mammals," but only a few mentioned "insects" or "fish" as food items. Worldwide, fish have appeared in the diets of Peregrine Falcons at widespread locations, with most cases being a single observation or anecdotal evidence (Bent 1938, Brown 1968, Merchant and Higgins 1993, Cade et al. 1996, Rockenbauch 2002). It seems if observations are made over long-enough periods, use of fish will be noted but not described as occurring regularly. Such observations are usually of peregrines seen with single fish, and the instances often are mentioned as unusual or partial observations. In describing the summer diet of Peregrine Falcons, Ellis et al. (2004) listed 793 birds, 7 mammals, and 9 insects from the prey remains found in 25 eyries in Arizona. White and Roseneau (1970) reviewed several interesting notes in the literature on Peregrine Falcons eating fish, as did Ratcliffe (1993). Some witnessed Peregrine Falcons catching fish (Cade 1960), and others observed Peregrine Falcons attempting to catch and pirate fish from an osprey (Bagg 1937; Brian Walton, personal communication with T. Cade, in Cade 1982). White and Roseneau (1970) reported what appeared to be caudal fins from fish on a Peregrine Falcon's eyrie ledge. R. Ambrose (personal communication) found fish scales at a Peregrine Falcon eyrie in interior Alaska. Here, I report on an adult female Peregrine Falcon that learned how to acquire fish and then continually exploited this unusual food resource to feed its nestlings.

While monitoring raptors for the National Park Service (NPS), I recorded nesting behavior with video equipment at a Peregrine Falcon eyrie in northern Arizona. The site is an old stick nest and has an open view, making it possible to video-record activity in the nest. In 2011, one video recorded what appeared to be a fish delivery by the female falcon to her nestlings. The video was low quality, and I assumed that it showed the body of a plucked bird with some parts already removed. The video was recorded when the young were near fledging, and I had not seen anything like this food delivered previously.

In 2012, using a higher-resolution camera, I recorded nesting activity once a week, over 5 weeks, from after hatching (11 June 2012) to fledging (16 July 2012). During the first video recording period, the adult female returned to the eyrie bearing a fish from her hunt (Fig. 1). In the successive weeks, the only time she was seen taking birds to the eyrie was when the male had given them to her during an in-air food transfer. Whenever she was gone from the eyrie for an extended period of time, she returned with a fish. In total, this adult female

1412 Hanby Ave., Bishop, CA 93514. E-mail: bbhetzler@aol.com 


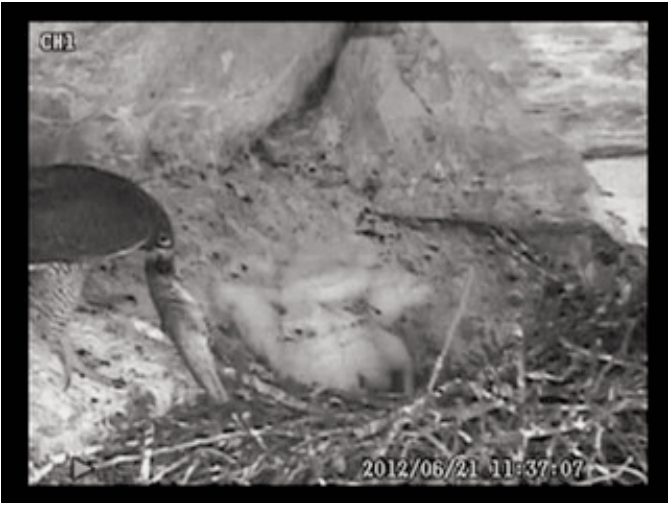

Fig. 1. Video screen capture of an adult female Peregrine Falcon delivering a fish to the eyrie, 21 June 2012.

TABLe 1. Food deliveries to young by adult Peregrine Falcons.

\begin{tabular}{llll}
\hline Date & Time & Adult & Prey \\
\hline 13 July 2011 & $12: 51$ & Female & Fish \\
2 1 June 2012 & $11: 37$ & Female & Fish \\
21 June 2012 & $11: 46$ & Male & Bird \\
3 July 2012 & $08: 48$ & Female & Bird $^{a}$ \\
3 July 2012 & $10: 48$ & Male & Bird \\
3 July 2012 & $11: 24$ & Male & Bird \\
3 July 2012 & $12: 01$ & Female & Fish \\
11 July 2012 & $09: 27$ & Male & Bird \\
11 July 2012 & $10: 07$ & Female & Fish \\
11 July 2012 & $11: 38$ & Male & Bird \\
11 July 2012 & $14: 14$ & Female & Fish \\
11 July 2012 & $17: 07$ & Female & Birda \\
16 July 2012 & $11: 00$ & Female & Fish \\
16 July 2012 & $13: 37$ & Female & Fish \\
16 July 2012 & $13: 50$ & Male & Bird \\
16 July 2012 & $16: 05$ & Female & Fish \\
\hline
\end{tabular}

aPrey taken from male during in-air food exchange.

was seen delivering fish to her young on 8 occasions over 5 days, each sampling day about one week apart (Table 1). After the young had fledged, we no longer collected video recordings, but, during site visits, we still observed fish being delivered to the young fledglings. It is likely that this adult female was bringing in fish daily, during the periods when we were not present. The nearest body of water containing fish was approximately $2 \mathrm{~km}$ from the nest site. I checked this water body and others nearby but did not see any peregrines taking or flying with fish. The fish brought to the eyrie appear to be rainbow trout (C.N. Medley, personal communication, NPS fish biologist).

Although I have observed peregrines pirat- ing prey from other birds on many occasions, the multiple occurrences of fish deliveries to the eyrie suggest that this female had learned to catch fish on her own, probably picking them up in shallow waters of several nearby lakes that were at very low levels. Ratcliffe (1993) mentioned that individual birds are likely to exploit any productive feeding place; this female peregrine apparently discovered just such a productive feeding place where fish could be taken easily. She then made repeated deliveries of fish to her young rather than hunt for birds. Although a Peregrine Falcon catching and utilizing fish in its diet is not unheard of, this observation shows an unusual aspect of this behavior. The falcon I observed not only exploited a productive feeding place, but targeted a prey species not normally taken by peregrines. She then used this food to care for her young. She accomplished all this while also having learned to capture prey in a manner that is likely remarkably different from how she would normally hunt. This bird, by learning a new technique for hunting, was able to switch over to and exploit an abundant alternative food source.

\section{Literature Cited}

BAGG, A.S. 1937. Birds of the Connecticut Valley, Massachusetts. Hampshire Bookshope, Boston, MA.

BEnT, A.C. 1938. Life histories of North American birds of prey, Order Falconiformes. Dover Publications, New York, NY.

Brown, H.L. 1968. Eagles, hawks and falcons of the world. Hamlyn Publishing Group, Ltd., Middlesex, Great Britain.

Cade, T.J. 1960. Ecology of the Peregrine and Gyrfalcon populations in Alaska. University of California Press, Berkeley, CA. Pp. 151-290.

1982. The falcons of the world. Cornell University Press, Ithaca, NY.

Cade, T.J., M. Martell, P. Redig, G.A. Septon, and H.B. ToRDOFF. 1996. Peregrine Falcons in urban North America. Pages 3-13 in D. Bird, D. Varland, and J. Negro, editors, Raptors in human landscapes. Academic Press, New York, NY.

ElLIS, D.H. 2004. Summer diet of the Peregrine Falcon in faunistically rich and poor zones of Arizona analyzed with capture-recapture modeling. Condor 106: 873-886.

Merchant, S., and P.J. Higgins, editors. 1993. Handbook of Australia, New Zealand and Antarctic birds. Volume 2. Oxford University Press, Melbourne, Australia.

Ratcliffe, D. 1993. The Peregrine Falcon. T. \& A.D. Poyser, London, United Kingdom.

Rockenbauch, D. 2002. Der Wanderfalke in Deutschland und umliegenden Gebieten. Verlag Christine Hölzinger, Ludwigsburg, Germany. 
Sherrod, S. 1978. Diets of North American Falconiformes. Journal of Raptor Research 12:49-121.

White, C.M., N.J. Clum, T.J. Cade, and W.G. Hunt. 2002. Peregrine Falcon (Falco peregrinus). No. 660 in A. Poole and F. Gill, editors, The birds of North America. The Birds of North America, Inc., Philadelphia, PA.
White, C.M., And D.G. Roseneau. 1970. Observations on food, nesting, and winter populations of large North American falcons. Condor 72:113-115.

Received 4 October 2012 Accepted 16 November 2012 